\title{
The Effect of a Proposed Training Program Based on the Reflective Model on the Development of the Ninth Grade Students' English Reading Comprehension Skills in Mafraq
}

\author{
Fawwaz Al-Abed Al-Haq \\ Yarmouk University, Irbid, Jordan
}

\author{
Asma Ahmed Alimoush \\ Tabuk University, Tabuk, Saudi Arabia
}

\begin{abstract}
This study aimed at investigating the effect of a proposed EFL (English as a Foreign Language) training program based on the reflective model on the development of the ninth grade students' English reading comprehension skills in Mafraq. The participants of the study were 100 ninth grade students who represented the experimental and control groups. To achieve the purposes of the study, the researcher designed a pre and post achievement test for students. The results of the study showed that there were statistically significant differences at the level of $(\alpha=0.05)$ between the means scores of the ninth grade students' performance of the control and experimental groups on the post achievement test in favor of the experimental group due to the training program. It is recommended that training programs should focus on providing students with explicit strategy instruction that enables them to become independent learners and good readers.
\end{abstract}

Keywords: teacher training programs, reflective model, reading comprehension practices, English reading comprehension skills

\section{Introduction}

The late 20th century has been called the age of communication. The world is very rapidly transforming into the global village that is characterized by a rapid change and explosion of information. As the pressure to communicate increases, learning languages, especially which are seen as international channels of communication, become a necessity to cope with the demands of the age of communication. Recently, the reading skill is viewed as a significant skill that enables individuals to cope with this global world. There is no doubt that reading enhances one's knowledge and information, enables individual to participate in multilingual communities around the world, broadens better understanding of other cultures, and develops other language skills.

According to Grabe (1991), reading is an essential skill and probably the most important skill for learners to master in academic contexts. This idea is supported by Brodsky (2011) who emphasized that reading is the basic foundation on which academic skills of students are built. He added that reading skills and strategies enhance the child's capacity to comprehend various concepts, develop critical thinking skills, and improve the person's vocabulary, communication skills, and concentration ability. According to Eskey (1988), in advanced 
levels of second language, the ability to read the written language at a reasonable rate and with good comprehension has long been recognized to be as the most important oral skills.

There have been a number of definitions of reading, yet it is not a simple matter to define it in a one sentence. For example, according to Snow (2002), reading comprehension is constructing meaning from written language through an interactive process in which the reader interacts and involves with the text using his capacities, abilities, knowledge, and experiences. Thus comprehension requires three elements: the reader who comprehends the text; the text; the act of reading in which comprehension is a part. The act of reading includes the purposes and processes.

Chastain (1988) defined reading as an active cognitive system operating on printed material in order to comprehend the text. According to Grabe and Stoller (2002) reading is "...the ability to draw meaning from the printed page and interpret this information appropriately" (p. 9).

Having in mind the importance of reading comprehension, a good question might be raised in this regard: What kind of instruction best promotes the development of students' comprehension skills? Armbruster and Osborn (2003) stated that too many children in today's schools struggle with learning to read. They added that many teachers and parents believe that reading failure has a bad impact upon children's self-confidence development and motivation, as well as for their later school success. Therefore, helping students become good second language readers has got scholars concerns for many years. As a result, remarkable volume of research has been accumulated. Despite this, little has been known about how people become good second/foreign language readers. Since a testable, coherent theory that explains second language reading and how it is learned has not been formed yet (Hedgcock \& Ferris, 2009).

Nevertheless, Hedgcock and Ferris pointed out that an acceptable understanding of second/foreign language reading, and powerful insights for teaching can be gained from exploring research contributions. In line with Hedgcock and Ferris, Armbruster and Osborn (2003) stated that teaching reading is not a simple matter. They clarified that there is no rapid solution to improve the development of reading skills. Yet, they explained that present knowledge base helps us to recognize what skills that children must learn in order to read well.

In this context, Block and Israel (2005) maintained that teachers can help improve students' comprehension through instructional reading strategies that include modeling, thinking aloud, inferring, summarizing, making connections, questioning, predicting, etc. Research has suggested that comprehension strategies can be taught, and when taught, can develop better processing systems that increase comprehension (Center, Freeman, Robertson, \& Outhred, 1999; Gambrell \& Jawitz, 1993). Carrell (1998) maintained that effective comprehension strategies give the students opportunity to elaborate, organize, and evaluate text information.

Further, the National Reading Panel (2000) emphasized that comprehension strategies are critically important to build good readers. So, helping students construct meaning from text is an essential and often difficult task especially when many learners lack effective reading strategies that will guide them in the process. According to Sarah (2009), the implicit premise is that students who actively engage in particular cognitive and metacognitive strategies (e.g., predicting, previewing, summarizing, questioning, skimming, monitoring, text structure, and semantic mapping) are expected to comprehend and recall more of what they read because these strategies enable students to monitor and evaluate their reading process. In addition, Duke and Pearson (2005) indicated that there is strong evidence that students can be taught reading comprehension strategies and that 
such training is effective at progressing their understanding of the text they read.

There is an agreement among educationalists and practitioners that well-trained and qualified teachers can help their students to become good readers. Many researchers have made the link between high-quality teaching and student learning (American Education Research Association, 2005; Darling-Hammond, 2000; Guskey, 2000; Joyce \& Showers, 1988; Naik, 2004; Sanders \& Rivers, 1996; Sparks \& Loucks-Horsley, 1989; Taylor, Pearson, Peterson, \& Rodriguez, 2005). Naik (2004) asserted that the teacher is the key practitioner in the field of education. Darling-Hammond (2000) who examined the ways in which teacher qualifications and other school inputs are related to student achievement concluded that the quality of teachers affects students' achievement.

\section{Problem and Significance of the Study}

The Ministry of Education in Jordan (2010) explored the eighth grade students' common errors in the area of reading comprehension (p. 9). The findings showed that eighth grade students committed a number of errors while reading. For example, students were unable to skim text to identify the main idea, scan the text to identify relevant information, scan the text to make use of information, scan text to make inferences, analyze to make use of pronoun, scan text to make decisions, skim a text to infer for reasoning.

The researcher concluded from the findings that students' basic reading comprehension skills are nonexistent and they need to be developed. Many reasons contributed to this. Yet, the most important reason might be the types of instruction delivered to those students. Research indicates that students are not likely to use reading skills and strategies as they read, without being aware of their value. Besides, other students do not realize that reading requires active thinking as they read (Hedgcock \& Ferris, 2009). Therefore, the researcher developed an EFL training program based on the reflective model to achieve two aims: first, enhancing and improving the EFL teachers' reading practices; second, developing the ninth grade students' reading comprehension skills.

\section{Purpose and Questions of the Study}

This study aimed at investigating the indirect impact of a proposed training program based on the reflective model on the development of the ninth grade students' reading comprehension skills. This study attempted to answer the following question:

Are there any significant differences between the means scores of the ninth grade students' performance of the control and experimental groups on the pre and post achievement test due to the training program?

\section{Operational Definitions of Terms}

The following terms will have the associated meanings whenever they appear in this study:

The conventional reading comprehension teaching procedures: They are the procedures that are included in the Action Pack Teacher's book to help teachers carry out reading comprehension lessons. These procedures recommend teachers to brainstorm students and answer the student's book pre-reading questions before reading, then answer the student's book while-reading questions.

Reading comprehension: It is constructing meaning from written language through an interactive process in which the reader interacts and involves with the text using his capacities, abilities, knowledge, and experiences. 
Reading comprehension skills: They are the abilities for deducing the meaning and use of unfamiliar lexical items through understanding word formation, understanding relations within the sentence especially elements of sentence structure, skimming to obtain the main idea of the text, understanding relations between parts of a text through cohesion devices, understanding relations between parts of a text through grammatical devices, summarizing information into a semantic map, understanding information when explicitly stated (extract specific explicit information), understanding information when not explicitly stated (making inferences), comparing ideas, and thinking critically.

Teachers' reading practices: They are the teachers' performances regarding teaching reading comprehension. They also refer to the techniques that are used by the teachers to teach reading comprehension including using previewing strategy, predicting strategy, skimming strategy, examining cohesive ties strategy, examining syntactic information, question-answering strategy, and semantic mapping strategy to teach reading comprehension, formulating lesson plans that implement the strategies mentioned above, and using systematic observation strategy to gather information about the students' strategies implementation.

Training program: It is a purposeful plan that aimed at enhancing and improving the EFL teachers' reading practices, and the students' reading comprehension skills. The program has two foundations: the training foundation that is based on the reflective model for teacher education, and the instructional foundation that is based on the cognitive and metacognitive strategies of reading. Thus, it focused on previewing strategy, predicting strategy, skimming strategy, examining cohesive ties strategy, examining syntactic information strategy, question-answering strategy, and semantic mapping strategy.

Reflective model: It is a reflective training model for teacher education. It aims to develop the professional competence through engaging the trainees in continuing process of reflection on the received knowledge and experiential knowledge.

Comprehension strategies: They are deliberate and conscious plans for gathering, evaluating, and using text information to construct meaning.

Previewing strategy: It is a pre-reading strategy that involves reading over key parts of a text, such as the title, subheadings, bold and italicized words, figures, and tables.

Predicting strategy: It is a pre-reading strategy that involves telling or stating what will happen in the future on the basis of special knowledge. Predicting involves making conclusions through a process of logical thinking.

Skimming strategy: It is a pre-reading strategy used to get the main idea of a text and to familiarize the readers with the text before reading it in depth.

Examining cohesive ties strategy: It is a while-reading cognitive strategy which aims at looking closely at text cohesion through examining cohesive devices (e.g., pronouns reference, synonyms, conjunction, and so forth).

Examining syntactic information strategy: It is a while-reading cognitive strategy which aims at looking closely at syntax structures of a text (e.g., sentence components, relative clauses, noun phrases, tenses, passive voice, adverbials, and so forth).

Question-answering examining: It is a while-reading cognitive strategy that helps readers make meaning of the text through looking for answers of given questions.

Semantic mapping strategy: It is a post-reading strategy that gives the reader a visual representation for expository and narratives texts. 


\section{Limitations of the Study}

The following points can be considered as limitations to the generalization of the findings of the present study:

(1) The present study is limited to the in-service EFL female teachers who teach the ninth grade and the ninth grade students at the Northwestern Badia Directorate of Education during the academic year 2011-2012. So, the findings of the study are generalizable only to similar educational contexts in Jordan;

(2) The present study relied on training EFL teachers to improve limited number of reading practices;

(3) The present study aimed to improve limited number of reading comprehension skills among students.

\section{Methods and Procedures}

This section presents the methodology which the researcher followed in this study. It includes the design of the study, participants of the study, instruments, validity, and reliability of the instruments, the training program (objectives and description), data collection procedures, and the statistical analysis.

\section{Design of the Study}

A quasi-experimental design was used in order to conduct this study. Quantitative data were collected through a pre and post achievement test. The question of the study was analyzed using means, standard deviations, estimated marginal, MANCOVA, and ANCOVA.

\section{Participants of the Study}

The participants of this study were 100 ninth grade female students who were purposefully selected from Al-Hemra secondary school for girls, and assigned randomly to two groups as follows: The experimental group consisted of 50 female students taught by teachers who participated in the current training program; the control group consisted of 50 female students taught by teachers who did not participate in the current training program.

\section{Instruments of the Study: Their Validity and Reliability}

The researcher has developed the following instruments in order to achieve the purposes of the present study.

\section{Teacher Training Program}

The researcher designed a training program based on the reflective model to acquaint the teachers with sufficient knowledge that may enable them to teach reading comprehension more effectively.

Objectives of the training program. This training program aimed to:

(1) Engaging the trainees into a continuing reflective process to develop the following teachers' reading practices: using previewing strategy, using predicting strategy, using skimming strategy, using questions-answering strategy, examining text cohesive ties and syntactic information of the text strategies, using semantic mapping strategy, formulating lesson plans that implement the strategies mentioned above, using systematic observation strategy to gather evaluate the students' strategies implementation;

(2) Developing the following students' reading comprehension skills: (a) word-attack skill: deducing the meaning and use of unfamiliar lexical items through understanding word formation; (b) sentence-attack skill: understanding relations within the sentence especially elements of sentence structure; and (c) text-attack skills: skimming to obtain the main idea of the text, understanding relations between parts of a text through cohesive devices, understanding relations between parts of a text through grammatical devices, summarizing information 
into a semantic map, understanding information when explicitly stated (extract specific explicit information), understanding information when not explicitly stated (making inferences), comparing ideas, thinking critically.

Proposed approach and methodology of the training program. The current training program was based on two foundations: the training foundation that is based on the reflective model for teacher education, and the instructional foundation that is based on the cognitive and metacognitive strategies of reading. According to the reflective model, the professional competence stems from engaging the trainees in the continuing process of reflection on the received and experiential knowledge. To achieve this, first, the trainees play an active role in designing and implementing teaching actions. Then, they engage in continuing process of reflection on received knowledge and experiential knowledge in the context of professional action. In light of the reflective model, the current training program utilized a spectrum of training contexts ranging from minimum cost contexts at one end to autonomous professional action at the other. These training contexts were: planning and designing activities, microteaching, systematic self-observation, collaborative supervision and teaching practice, and autonomous professional action.

\section{The Students' Pre and Post Achievement Test}

The researcher constructed a pre and post achievement test to measure the effect of the current training program on the development of the ninth grade students' reading comprehension skills. The achievement test included three reading comprehension texts: The Houseboats of Kashmir, Stella's Daily Activities, and Mountain Story. The test was distributed to 100 female students. They were asked to answer the questions on the same paper of the test. The test was marked according to the answer key. The total mark of the test was 50 .

Validity of the test. A jury of three EFL university professors, a measurement and evaluation university professor, and seven EFL supervisors were kindly requested to determine the validity of the test. They were asked to ensure its content validity. The jury suggested deleting a number of multiple-choice items. They believed that those items were similar to other items and measured the same points. So, the researcher deleted the similar items and those items that were vague and misleading.

Reliability of the test. The test was administered to a sample of 37 ninth grade students who did not participate in the study. It was administered after two weeks on the same sample to assess its reliability. The results were calculated and analyzed. The test-retest coefficient was 0.83 and KR-20 formula was 0.87 in which both were considered acceptable for the purpose of this study.

\section{Variables of the Study}

The variables of the study were the following:

(1) The independent variable: the current training program;

(2) The dependent variables: students' English reading comprehension skills.

\section{Data Collection Procedures}

To carry out this study, the researcher followed following steps:

(1) Permission was taken from Northwestern Badia Directorate of Education to conduct the study;

(2) Choosing the samples of the study from the Northwestern Badia Directorate of Education;

(3) Designing the current training program establishing its validity;

(4) Meeting the teachers included in the experiment and trained them on the program;

(5) Giving the pre-post achievement test at the onset and the outset of the experiment. 


\section{Statistical Analysis}

To answer the research question, a proper statistical analysis was used. First, means, standard deviations, and estimated marginal means of the students' scores on the pre and post achievement test of the control and experimental groups prior to and after the application of the training program were calculated. Second, MANCOVA was conducted on the domains of the pre and post achievement test. Finally, ANOVA was conducted on the total of the achievement test.

\section{Results of the Study}

This section presents the results of the study concerning the effect of a proposed EFL training program based on the reflective model on the development of the ninth grade students' reading comprehension skills.

To answer the question of the study, "Are there any statistically significant differences at the level of ( $\alpha=$ 0.05 ) between the means scores of the ninth grade students performance of the control and experimental groups on the pre and post achievement test due to the training program?", first, means, standard deviations, and estimated marginal means of the ninth grade students performance of the control and experimental groups on the pre and post achievement test prior and after the application of the training program were calculated. Second, MANCOVA was conducted on the domains of the pre and post achievement test. Finally, ANOVA was conducted on the total of the pre and post achievement test. Table 1, Table 2, and Table 3 present the results.

Table 1

Means, Standard Deviations and Estimated Marginal Means of the Ninth Grade Students Performance of the Control and Experimental Groups on the Pre and Post Achievement Test

\begin{tabular}{|c|c|c|c|c|c|c|c|}
\hline \multirow{2}{*}{ Reading comprehension skills } & \multirow[b]{2}{*}{ Group } & \multicolumn{2}{|r|}{ Pre } & \multicolumn{2}{|r|}{ Post } & \multirow{2}{*}{$\begin{array}{l}\text { Estimated } \\
\text { marginal means }\end{array}$} & \multirow{2}{*}{$\mathrm{N}$} \\
\hline & & Mean & Std. Deviation & Mean & Std. Deviation & & \\
\hline \multirow{3}{*}{$\begin{array}{l}\text { Deducing the meaning and use of } \\
\text { unfamiliar lexical items through } \\
\text { understanding word formation }\end{array}$} & Experimental & 2.18 & .800 & 3.00 & 639 & 2.89 & 50 \\
\hline & Control & 1.88 & .824 & 1.88 & .824 & 1.99 & 50 \\
\hline & Total & 2.03 & .822 & 2.44 & .925 & 2.44 & 100 \\
\hline \multirow{3}{*}{$\begin{array}{l}\text { Understanding relations within the } \\
\text { sentence especially elements of } \\
\text { sentence structure }\end{array}$} & Experimental & 2.08 & .566 & 2.80 & .404 & 2.85 & 50 \\
\hline & Control & 2.12 & .328 & 2.12 & .328 & 2.07 & 50 \\
\hline & Total & 2.10 & .461 & 2.46 & .501 & 2.46 & 100 \\
\hline \multirow{3}{*}{$\begin{array}{l}\text { Skimming to obtain the main idea } \\
\text { of the text }\end{array}$} & Experimental & 3.50 & 1.093 & 3.96 & 1.009 & 3.97 & 50 \\
\hline & Control & 3.56 & 1.181 & 3.56 & 1.181 & 3.55 & 50 \\
\hline & Total & 3.53 & 1.132 & 3.76 & 1.111 & 3.76 & 100 \\
\hline \multirow{3}{*}{$\begin{array}{l}\text { Understanding relations between } \\
\text { parts of a text through cohesion } \\
\text { devices }\end{array}$} & Experimental & 3.02 & .622 & 3.84 & .792 & 3.91 & 50 \\
\hline & Control & 3.20 & .948 & 3.20 & .948 & 3.13 & 50 \\
\hline & Total & 3.11 & .803 & 3.52 & .926 & 3.52 & 100 \\
\hline \multirow{3}{*}{$\begin{array}{l}\text { Understanding relations between } \\
\text { parts of a text through } \\
\text { grammatical devices }\end{array}$} & Experimental & 2.28 & .454 & 2.88 & .328 & 2.90 & 50 \\
\hline & Control & 2.30 & .463 & 2.28 & .454 & 2.26 & 50 \\
\hline & Total & 2.29 & .456 & 2.58 & .496 & 2.58 & 100 \\
\hline
\end{tabular}


(Table 1 continued)

\begin{tabular}{|c|c|c|c|c|c|c|c|}
\hline \multirow{2}{*}{ Reading comprehension skills } & \multirow[b]{2}{*}{ Group } & \multicolumn{2}{|r|}{ Pre } & \multicolumn{2}{|r|}{ Post } & \multirow{2}{*}{$\begin{array}{l}\text { Estimated } \\
\text { marginal means }\end{array}$} & \multirow{2}{*}{$\mathrm{N}$} \\
\hline & & Mean & Std. Deviation & Mean & Std. Deviation & & \\
\hline \multirow[t]{3}{*}{$\begin{array}{l}\text { Summarizing information into a } \\
\text { semantic map }\end{array}$} & Experimental & 2.08 & .634 & 2.76 & .517 & 2.80 & 50 \\
\hline & Control & 2.14 & .606 & 2.16 & .584 & 2.12 & 50 \\
\hline & Total & 2.11 & .618 & 2.46 & .626 & 2.46 & 100 \\
\hline \multirow{3}{*}{$\begin{array}{l}\text { Understanding information when } \\
\text { explicitly stated (extract specific } \\
\text { explicit information) }\end{array}$} & Experimental & 3.40 & .904 & 4.08 & .853 & 4.10 & 50 \\
\hline & Control & 3.48 & .909 & 3.44 & .951 & 3.42 & 50 \\
\hline & Total & 3.44 & .903 & 3.76 & .955 & 3.76 & 100 \\
\hline \multirow{3}{*}{$\begin{array}{l}\text { Understanding information when } \\
\text { not explicitly stated(making } \\
\text { inferences) }\end{array}$} & Experimental & 2.68 & .978 & 3.00 & .904 & 3.08 & 50 \\
\hline & Control & 2.84 & .842 & 2.84 & .817 & 2.76 & 50 \\
\hline & Total & 2.76 & .911 & 2.92 & .861 & 2.92 & 100 \\
\hline \multirow[t]{3}{*}{ Comparing ideas } & Experimental & 3.20 & 1.069 & 3.92 & 1.066 & 3.98 & 50 \\
\hline & Control & 3.28 & .970 & 3.30 & .953 & 3.24 & 50 \\
\hline & Total & 3.24 & 1.016 & 3.61 & 1.053 & 3.61 & 100 \\
\hline \multirow[t]{3}{*}{ Thinking critically } & Experimental & 3.20 & 1.212 & 4.00 & 1.069 & 4.07 & 50 \\
\hline & Control & 3.28 & 1.196 & 3.28 & 1.196 & 3.21 & 50 \\
\hline & Total & 3.24 & 1.199 & 3.64 & 1.185 & 3.64 & 100 \\
\hline \multirow[t]{3}{*}{ Total } & Experimental & 27.56 & 6.713 & 34.24 & 6.063 & 34.46 & 50 \\
\hline & Control & 28.04 & 6.468 & 27.96 & 6.543 & 27.74 & 50 \\
\hline & Total & 27.80 & 6.563 & 31.10 & 7.024 & 31.10 & 100 \\
\hline
\end{tabular}

It can be concluded from Table 1 that the means scores of the ninth grade students' performance of the experimental group on the pre achievement test range from 2.08 to 3.50 prior to the application of the training program. The highest is skimming to obtain the main idea of the text, while the lowest are understanding relations within the sentence especially elements of sentence structure, and summarizing information into a semantic map. It also can be concluded that the means scores of the ninth grade students' performance of the experimental group on the post achievement test range from 2.80 to 4.08 after the application of the training program. The highest is understanding information when explicitly stated (extract specific explicit information), whereas the lowest is understanding relations within the sentence especially elements of sentence structure. These results showed that the means scores of the ninth grade students' performance of the experimental group on the post achievement test rose dramatically after involving their teachers in the training program. The researcher concluded that this may refer to the training program that has a positive effect on developing the teachers professionally, which in turn developed students' reading comprehension skills.

In contrast, since the teachers of the control group were not involved in the training program, the means scores of the ninth grade students' performance of the control group on the post achievement test nearly remained the same. The means range from 1.88 to 3.56 prior the application of the training program for the teachers of the experimental group. The highest is skimming to obtain the main idea of the text, while the lowest is deducing the meaning and use of unfamiliar lexical items through understanding word formation. The means range from 1.88 to 3.56 after the application of the training program for the experimental group. The highest is skimming to obtain the main idea of the text, while the lowest is deducing the meaning and use of unfamiliar lexical items through understanding word formation. 
To determine the significance of these differences between the means of the experimental and control groups, MANCOVA was conducted on the domains of the achievement test. Results are presented in Table 2.

Table 2

MANCOVA Results on the Domains of the Pre and Post Achievement Test of the Experimental and Control Groups

\begin{tabular}{|c|c|c|c|c|c|c|}
\hline Source & Dependent variable & $\begin{array}{l}\text { Sum of } \\
\text { squares }\end{array}$ & $\mathrm{df}$ & Mean square & $\mathrm{F}$ & Sig. \\
\hline \multirow{10}{*}{$\begin{array}{l}\text { Group } \\
\text { Hotelling's trace }= \\
5.109 \\
\mathrm{P}=.000\end{array}$} & $\begin{array}{l}\text { Deducing the meaning and use of unfamiliar lexical } \\
\text { items through understanding word formation }\end{array}$ & 17.225 & 1 & 17.225 & 186.249 & .000 \\
\hline & $\begin{array}{l}\text { Understanding relations within the sentence } \\
\text { especially elements of sentence structure }\end{array}$ & 12.847 & 1 & 12.847 & 212.477 & .000 \\
\hline & Skimming to obtain the main idea of the text & 3.814 & 1 & 3.814 & 26.596 & .000 \\
\hline & $\begin{array}{l}\text { Understanding relations between parts of a text } \\
\text { through cohesion devices }\end{array}$ & 12.992 & 1 & 12.992 & 91.767 & .000 \\
\hline & $\begin{array}{l}\text { Understanding relations between parts of a text } \\
\text { through grammatical devices }\end{array}$ & 8.879 & 1 & 8.879 & 113.078 & .000 \\
\hline & Summarizing information into a semantic map & 9.652 & 1 & 9.652 & 61.530 & .000 \\
\hline & $\begin{array}{l}\text { Understanding information when explicitly stated } \\
\text { (extract specific explicit information) }\end{array}$ & 9.535 & 1 & 9.535 & 54.783 & .000 \\
\hline & $\begin{array}{l}\text { Understanding information when not explicitly } \\
\text { stated (making inferences) }\end{array}$ & 2.200 & 1 & 2.200 & 14.558 & .000 \\
\hline & Comparing ideas & 11.227 & 1 & 11.227 & 69.914 & .000 \\
\hline & Thinking critically & 15.595 & 1 & 15.595 & 202.392 & .000 \\
\hline \multirow[t]{10}{*}{ Error } & $\begin{array}{l}\text { Deducing the meaning and use of unfamiliar lexical } \\
\text { items through understanding word formation }\end{array}$ & 8.138 & 88 & .092 & & \\
\hline & $\begin{array}{l}\text { Understanding relations within the sentence } \\
\text { especially elements of sentence structure }\end{array}$ & 5.321 & 88 & .060 & & \\
\hline & Skimming to obtain the main idea of the text & 12.620 & 88 & .143 & & \\
\hline & $\begin{array}{l}\text { Understanding relations between parts of a text } \\
\text { through cohesion devices }\end{array}$ & 12.459 & 88 & .142 & & \\
\hline & $\begin{array}{l}\text { Understanding relations between parts of a text } \\
\text { through grammatical devices }\end{array}$ & 6.910 & 88 & .079 & & \\
\hline & Summarizing information into a semantic map & 13.804 & 88 & .157 & & \\
\hline & $\begin{array}{l}\text { Understanding information when explicitly stated } \\
\text { (extract specific explicit information) }\end{array}$ & 15.317 & 88 & .174 & & \\
\hline & $\begin{array}{l}\text { Understanding information when not explicitly } \\
\text { stated (making inferences) }\end{array}$ & 13.297 & 88 & .151 & & \\
\hline & Comparing ideas & 14.131 & 88 & .161 & & \\
\hline & Thinking critically & 6.781 & 88 & .077 & & \\
\hline \multirow[t]{10}{*}{ Corrected total } & $\begin{array}{l}\text { Deducing the meaning and use of unfamiliar lexical } \\
\text { items through understanding word formation }\end{array}$ & 84.640 & 99 & & & \\
\hline & $\begin{array}{l}\text { Understanding relations within the sentence } \\
\text { especially elements of sentence structure }\end{array}$ & 24.840 & 99 & & & \\
\hline & Skimming to obtain the main idea of the text & 122.240 & 99 & & & \\
\hline & $\begin{array}{l}\text { Understanding relations between parts of a text } \\
\text { through cohesion devices }\end{array}$ & 84.960 & 99 & & & \\
\hline & $\begin{array}{l}\text { Understanding relations between parts of a text } \\
\text { through grammatical devices }\end{array}$ & 24.360 & 99 & & & \\
\hline & Summarizing information into a semantic map & 38.840 & 99 & & & \\
\hline & $\begin{array}{l}\text { Understanding information when explicitly stated } \\
\text { (extract specific explicit information) }\end{array}$ & 90.240 & 99 & & & \\
\hline & $\begin{array}{l}\text { Understanding information when not explicitly } \\
\text { stated (making inferences) }\end{array}$ & 73.360 & 99 & & & \\
\hline & Comparing ideas & 109.790 & 99 & & & \\
\hline & Thinking critically & 139.040 & 99 & & & \\
\hline
\end{tabular}


Table 2 shows that there are statistically significant differences at $(\alpha=0.05)$ between the control and experimental groups in the post achievement test due to training program variable in favor of experimental group. This may due to the extent of improvement, and the amount of benefit the teachers got through training which was reflected in the students' reading comprehension performance.

Further, to determine the significance of the differences between the means of the experimental and control groups, ANCOVA was conducted on total of the achievement test. Results are presented in Table 3.

Table 3

ANCOVA Results on the Total of the Achievement Test of the Experimental and Control Groups

\begin{tabular}{llllll}
\hline Source & Sum of squares & df & Mean square & F & Sig. \\
\hline Pre test & 3454.476 & 1 & 3454.476 & 753.736 & .000 \\
Group & 1124.863 & 1 & 1124.863 & 245.435 & .000 \\
Error & 444.564 & 97 & 4.583 & & \\
Corrected total & 4885.000 & 99 & & & \\
\hline
\end{tabular}

As can be seen in Table 3 , there are statistically significant differences at $(\alpha=0.05)$ between the experimental and control groups in the total achievement test due to the training program variable in favor of the experimental group. This of course proves once again that the training had a positive effect on developing the teachers professionally. The teachers got a lot of benefit, besides; they put what they received into practice which improved students' comprehension.

\section{Discussions of the Results}

Tables 1, 2, and 3 showed that there were statistically significant differences at $(\alpha=0.05)$ between the control and experimental groups in the post achievement test due to the training program variable in favor of the experimental group whose teachers had participated in the training program under study as compared to the control group whose teachers had not participated in the training program. The result can be attributed to many factors. One of the main factors was the extent of improvement, and the amount of benefit the teachers got through training which was reflected in the students' reading comprehension performance.

In other words, the researcher concluded that this means that there was a positive relationship between the current training program, teachers' reading comprehension practices and students' English reading comprehension skills. This could be due to the fact that the ultimate justification for teacher training programs is to improve students' learning since the success of such programs is measured based on the reading comprehension skills development. This result was in line with these of Boatman (2003), Boone (2009), Conly (2005), Denise (2003), Forte (1999), Roy (2000), and Walizer (2004) which support the fact that good training programs can positively affect teachers' classroom practices and can consequently improve students' learning.

At the same time, the previous result contradicted with the result of Thompson's (2008) and Lesley's (2010) studies. Thompson's study indicated that the DRA training program did not have a statistically significant effect on the third grade students' reading achievement scores. This contradiction might be due to the inconsistent coaching cycle of the coaches, and teacher attitudes toward change. Lesley's study (2010) revealed that teachers' participation in high quality professional development and the amount of professional development activities did not impact student achievement in reading, language arts, or mathematics.

Another factor that may contribute to the previous result was teaching reading texts using cognitive reading strategies included in the training program. For example, pre-reading strategies such as previewing, 
predicting, and skimming strategies help readers connect ideas across parts of the text, fill information not provided by the author, construct meaning, and use prior knowledge and previous text information to anticipate content or draw conclusions. Further, question-answering strategy permits readers to focus reading, encourage problem solving, improve search for answer and information, and clarify confusions. Besides, semantic mapping strategy aid readers to create mental images, use prior knowledge and text to construct pictures (meaning), promote creative thinking, enhance comprehension, and encourage personal response.

In fact, the positive effect of cognitive reading strategies on reading comprehension is supported by Al-Alwan (2012), Anstey and Freebody (1987), Brown (2004), Edler (1988), Erten and Karakas (2007), Graham (1993), Kamalizad and Jalilzadeh (2011), Karakas (2005), King, Biggs, and Lipsky (1984), Moghadam (2001), Peng, Hoon, Khoo, and Joseph (2007), Shang, and Chang-Chien (2010), and Zhaohua (2004).

\section{Conclusion}

The purpose of this study was to investigate the effect of a proposed EFL training program based on the reflective model on the development of the ninth grade students' English reading comprehension skills in Mafraq. It was found that the training program had a positive effect on students' reading comprehension skills. In addition, providing students with explicit strategy instruction enabled them to become independent learners and good comprehenders.

\section{Pedagogical Implications}

Based on the results of the study, the following implications can be drawn:

(1) Syllabus designers are invited to incorporate different cognitive reading comprehension strategies in curricula and textbooks;

(2) Teachers should realize the importance of implementing cognitive reading comprehension strategies when teaching reading comprehension;

(3) Training programs should focus on providing students with explicit strategy instruction that enables them to become independent learners and good readers;

(4) Teachers should be followed-up inside the classrooms while implementing what they were trained on to find solutions and suggestions for the problems they face. This could be achieved through collaborative supervision.

\section{Recommendations for Further Research}

Based on the results of the study, the researcher suggested the following recommendations:

(1) Studies should be conducted to examine the effect of using other reading comprehension strategies;

(2) Since research studies examining the link between training programs and students' achievement in English are rare in Jordan, further research in this area is in great need, particularly in response to the current reform efforts and the constant changing needs of students and teachers.

\section{References}

Al-Alwan, A. F. (2012). The effect of using metacognition reading strategies on the reading comprehension of Arabic texts. IJAES, 13, 1-18. Retrieved June 3, 2012 from EBSCOhost Masterfile Database.

American Educational Research Association. (2005). Teaching teachers: Professional development to improve student achievement. Washington: American Educational Research Association.

Anstey, M., \& Freebody, P. (1987). The effects of various pre-reading activities on children's literal and inferential comprehension. Reading Psychology, 8(3), 112-126. 
Armbruster, B. B., \& Osborn, J. (2003). Put reading first: The research building blocks for teaching children to read. Washington: National Institute for Literacy.

Block, C., \& Israel, S. (2005). Reading first and beyond: The complete guide for teachers and literacy coaches. Thousand Oaks, CA: Coruin Press.

Boatman, V. (2003). An investigation into the effect of long-Term staff development on teacher perceptions and reading achievement of young children (Unpublished doctoral dissertation, University of North Texas).

Boone, P. K. (2009). Linking professional development and student achievement in reading: Closing the gap for teacher and learner (Unpublished doctoral dissertation, Walden University).

Brodsky, J. (2011). The importance of reading. Retrieved June 29, 2010 from http://www.buzzle.com/articles/importance-of reading.html

Brown, G. S. (2004). The efficacy of question-answering instruction for improving year 5 reading comprehension (Unpublished doctoral dissertation, University of Western Sydney).

Carrell, P. (1998). Can reading strategies be successfully taught? The language teacher. Retrieved May 3, 2010 from http:// language.hyper.chubu.ac.jp/jalt/pub/tit/98/mar/carrel.html

Center, Y., Freeman, L., Robertson, G., \& Outhred, L. (1999). The effect of visual imagery training on the reading and listening comprehension of low listening comprehension in year 2. Journal of Research in Reading, 22, 241-256.

Chastain, K. (1988). Developing second language skills: Theory and practice (3rd ed.). Chicago: HBJ.

Conly, M. M. (2005). A study of teacher expectations, staff development for teachers, and mastery learning on student achievement in reading comprehension (Unpublished doctoral dissertation, Chicago University).

Darling-Hammond, L. (2000). Teacher quality and student achievement: A review of state policy evidence. Tempe, AZ: Education Policy Analysis Archives.

Denise, E. S. (2003). The influence of an early literacy professional development program's practices on title 1 second grade students achievement (Unpublished doctoral dissertation, Saint Louis University).

Duke, N., \& Pearson, P. (2005). Effective practices for development reading comprehension. Newark: International Reading Association.

Edler, K. W. (1988). The effect of using predictions on a reader's comprehension (Unpublished master thesis, University of Toledo).

Erten, I. H., \& Karakas, M. (2007). Understanding divergent influence of reading activities on the comprehension of short stories. The Reading Matrix, 7(3), 113-132.

Eskey, D. (1988). Holding in the bottom: An interactive approach to the problem of sound language readers. In P. L. Carrell, J. Devine, and D. E. Esky (Eds.), Interactive approaches to second language learning (pp. 130-152). New York: Cambridge University Press.

Forte, B. (1999). The impact of professional development on teacher performance and student achievement (Unpublished doctoral dissertation, University of Illinois, Urban, Champaign, USA).

Gambrell, L., \& Jawitz, P. (1993). Mental imagery, text illustrations, and children's story comprehension and recall. Reading Research Quarterly, 28, 264-276.

Grabe, W. (1991). Current developments in second language research. TESOL Quarterly, 25, 375-406.

Grabe, W., \& Stoller, L. F. (2002). Teaching and researching reading (p. 9). Harlow: Pearson Education.

Graham, L. (1993). Comparing two modes of teaching a question-answering strategy for enhancing reading comprehension: Didactic and self-Instructional training. Learn Disable Journal, 26(4), 270-279.

Guskey, T. (2000). Evaluating professional development. Thousand Oaks, CA: Corwin Press.

Hedgcock, J. S., \& Ferris, D. R. (2009). Teaching readers of English students, texts, and contexts. New York: Routledge.

Joyce, B., and Showers, B. (1988). Student achievement through staff development. New York: Longman.

Kamalizad, J., \& Jalilzadeh, K. (2011). Question-generation reading strategy of Iranian EFL learners. Sino-US English Teaching, 12(11), 731-736.

King, J. R., Biggs, S., \& Lipsky, S. (1984). Students' self-questioning and summarizing as reading study strategies. Journal of Reading Behavior, 3, 205-218.

Lesley, I .A. (2010). The effect of professional development activities of teachers on students' tennessee comprehensive assessment program (TCAP) scores (Unpublished doctoral dissertation, Tennessee State University).

Ministry of Education. (2010). The results of exploring common errors among the eighth grade students in English language. The Ministry of Education. 
Moghadam, M. K. (2008). The effect of strategies-based instruction on student's reading comprehension of ESP Texts. English for Specific Purposes World, 17(7). Retrieved on April 16, 2009 from www.esp-world.info

Naik, S. P. (2004). Theory of teacher training. New Delhi: J. L. Kuumar for Anmol Publications.

National Reading Panel. (2000). Teaching children to read: An evidence-based assessment of the scientific research literature on reading and its implications for reading instruction. Retrieved May 5, 2010 from http://www.nichd.gov./publications/nrp/smallbook.cfm

Peng, R. G., Hoon, T. L., Khoo, S. F., \& Joseph, I. M. (2007). Impact of question-answer-relationships on reading comprehension (Pei Chun Public School and Marymount Convent Ministry of Education, Singapore).

Roy, P. A. (2000). An evaluation of the efficacy of teachers' professional development of constructive instructional strategies and students achievement in a school district in Delaware (Unpublished doctorial dissertation, Wilmington College).

Sarah, E. (2009). Knowledge for teaching reading comprehension mapping the terrain (Unpublished doctoral dissertation, the University of Michigan, USA).

Shang, H. F., \& Chang-Chien, I. J. (2010). The effect of self questioning strategy on EFL learners' reading comprehension development. The International Journal of Learning, 17(2), 41-54.

Snow, C. E. (2002). Reading for understanding: Toward a research and development program in reading comprehension. Santa Monica: Rand.

Thompson, O. B. (2008). A case study: The influence of the Pennsylvania High School Coaching Initiative on the change of teachers' instructional practices and student achievement (Unpublished doctoral dissertation. Indiana University of Pennsylvania).

Walizer, B. R. (2004). The impact of preservice teacher guided reading tutorials on the achievement and attitude of second graders (Unpublished doctoral dissertation, Kansas State University).

Zhaohua, S. (2004). Effects of previewing and providing background knowledge on EFL reading comprehension of American documentary narratives. TESL Reporter, 37(2), 50-63. 